\title{
РОЛЬ ПОЛІЦЕЙСЬКОГО ОМБУДСМЕНА У ЗАХИСТІ ПРАВ І СВОБОД ЛЮДИНИ
}

Кравченко І. С.

Метою написання наукової статmі $\epsilon$ визначення ролі поліцейського омбудсмена у механізмі захисту прав і свобод людини. Зроблено висновок про те, що працівники управління забезпечення прав людини Національної поліції України фактично $\epsilon$ контролюючими органами, що дублюють функції декількох підрозділів Національної поліції України та Уповноваженого Верховної Ради України з прав людини. Наголошено на необхідності вироблення чіткого розмежування повноважень державних органів із метою ефективного захисту прав і свобод людини в нашій державі.

Ключові слова: омбудсмен, управління захисту прав людини, Уповноважений Верховної Ради України з прав людини, внутрішня безпека, інспекція з особового складу, Національна поліція, реформа.

Целью написания научной статьи является определение роли полищейского омбудсмена в механизме защиты прав и свобод человека. Сделан вывод о том, что сотрудники управления обеспечения прав человека Национальной полиции Украины фактически являются контролирующими органами, дублирующими функции нескольких подразделений Национальной полици Украины и Уполномоченного Верховной Рады Украины по правам человека. Отмечена необходимость выработки четкого разграничения полномочий государственных органов в челях эффективной защиты прав и свобод человека в нашем государстве.

Ключевые слова: омбудсмен, управление защиты прав человека, Уполномоченный Верховной Рады Украины по правам человека, внутренняя безопасность, инспекция по личному составу, Национальная полиция, реформа.

The purpose of writing a scientific article is to determine the role of the police ombudsman in the mechanism of protection of human rights and freedoms.

The supporters of the establishment of the police ombudsman institution emphasize that the National Police of Ukraine's Human Rights Department will promote the democratization and humanization of the standards of police work while carrying out its tasks, and will provide effective control over the lawfulness of staying in places of non-freedom. It is the subordination of the Human Rights Directorate to the National Police of Ukraine directly to the Head of the National Police of Ukraine as a guarantee of an independent, impartial attitude of ombudsmen to the accomplishment of the tasks.

It is concluded that the employees of the Office for the Protection of Human Rights of the National Police of Ukraine are in fact controlling bodies that duplicate the functions of several departments of the National Police of Ukraine and the authorized representative of the Verkhovna Rada of Ukraine on Human Rights. The expediency of functioning of this institute remains questionable in the conditions of reformation of the National Police according to the principles of economic use of forces and means. Areas of work of these divisions are limited to educational activities, establishing a dialogue with the public, analytical activities. The control, which is part of the powers of the National Police's human rights management departments, is limited to inspections of territorial units, but there are no official statistics on this issue. Taking into account the above, it can also be argued about the ineffectiveness of the activity of this struc- tural unit, which should identify the violations of human rights and take measures for those who committed these actions.

The necessity of creating a clear separation of powers of state bodies for the effective protection of human rights and freedoms in our state is stressed.

Key words: Ombudsman, Human rights protection office, Ukrainian Parliament Commissioner for human rights, internal security, personnel inspection, National Police, reform.

Постановка проблеми та її актуальність. Дотримання прав людини в діяльності державний органів Україні завжди залишається актуальним. Про це свідчать статистичні дані. Так, у 2017 році Європейський суд із прав людини (ЄСПЛ) ухвалив 87 рішень щодо справ, пов'язаних з Україною. У 82 з них було виявлене щонайменше одне порушення Конвенції про захист прав людини. Майже кожен десятий випадок, у якому було виявлене порушення, стосувався України. 3 України протягом 2017 року надійшло 4387 нових скарг до ЄСПЛ. Ця цифра утричі менша, ніж у 2014 році. Для порівняння, у 2016 році було 8644 скарги, тобто майже вдвічі більше, ніж у 2017 році. Станом на кінець 2017 року на розгляді в ЄСПЛ перебувало близько 7100 актуальних позовів, що стосуються України. Отже, вона опинилася на четвертому місці за кількість справ, що перебувають на розгляді суду [1].

Аналіз прийнятих рішень ЄСПЛ дає змогу зробити висновок про недосконалість вітчизняних норм, їх невідповідності європейським стандартам. При цьому, як наголошує В. Князєв, система юридичних гарантій прав і свобод громадянина потребує не тільки нормативно-правових, але й інституційно-організаційних засобів їх забезпечення та захисту [2, с. 29].

Отже, можемо говорити про необхідність комплексного підходу до вирішення питання дотримання прав людини в діяльності державних органів України в цілому та Національної поліції зокрема.

Аналіз останніх досліджень і публікацій. Дослідження окремих питань щодо місця і ролі поліції у механізмі забезпечення прав людини і громадянина в Україні здійснено в роботах таких учених: С. Бакіліної, С. Батуріна, В. Бачиніна, Н. Бутусова, Ю. Ветютнева, Д. Вовка, О. Воловик, Є. Єграфової, Л. Заморської, М. Кельмана, А. Козловського, М. Козюбри, С. Максимова, І. Оборотова, Н. Пархоменко, О. Пащуліна, О. Петришина, П. Рабіновича, С. Рабіновича, О. Скакун, В. Скоробагатової, С. Сливки, А. Соколової, 3. Соломко, В. Тація, Ю. Тихомирова, В. Трофименка, В. Трофимова та багато інших.

Метою статті $\epsilon$ визначення ролі поліцейського омбудсмена у механізмі захисту прав та свобод людини.

Виклад основного матеріалу. Захист прав та свобод людини $\epsilon$ основним завданням Національної поліції України, яке закріплено на законодавчому рівні

Кравченко І. С., 2019 
[3]. Водночас механізми захисту таких прав та свобод $\epsilon$ різноманітними за своєю суттю та змістом. Новелою сучасних структурних змін Національної поліції України $\epsilon$ створення у 2015 році інституту поліцейського омбудсмена - управління забезпечення прав людини, що являється спробою підвищення рівня забезпечення прав людини в Національній поліції.

Хто такий поліцейський омбудсмен? Фактично це посадова особа Національної поліції (поліцейський), яка здійснює свою діяльність в центральних та територіальних органах поліції з метою забезпечення охорони прав і свобод людей під час виконання покладених на поліцію завдань.

Чи не $\epsilon$ це дублюванням функцій інспекцій з особового складу Національної поліції, підрозділів внутрішньої безпеки Національної поліції, управлінь організаційно-аналітичного забезпечення та оперативного реагування Національної поліції України, та інших контролюючих органів? Адже саме усунення дублювання повноважень підрозділів Національної поліції було проголошено в реформі МВС України 2014 року як основний захід та напрям удосконалення.

Прихильники створення інституту поліцейського омбудсмена наголошують, що управління забезпечення прав людини Національної поліції України сприятиме демократизації та гуманізації стандартів роботи поліції під час виконання покладених на неї завдань, а також забезпечить дієвий контроль за дотриманням законності під час перебування осіб у місцях несвободи. Саме підпорядковування управління забезпечення прав людини Національної поліції України безпосередньо Голові Національної поліції України вважають гарантією незалежного, неупередженого ставлення омбудсменів до виконання поставлених завдань.

До основних завдань управління забезпечення прав людини Національної поліції України належить забезпечення контролю за дотриманням прав і свобод людини працівниками поліції при забезпеченні заходів з підтримання публічної безпеки та порядку, під час виявлення та розкриття злочинів, запобігання адміністративним і кримінальним правопорушенням та протидії злочинності, досудового розслідування кримінальних правопорушень, виконання інших завдань, покладених на поліцію, а також здійснення контролю за роботою органів і підрозділів поліції з питань охорони осіб, затриманих за підозрою в учиненні кримінальних правопорушень, осіб, стосовно яких застосовано запобіжний захід у вигляді тримання під вартою, та засуджених осіб, їх доставляння під час досудового слідства, проведення з ними слідчих дій, розгляду справ у судах, забезпечення виконання постанов суду про адміністративний арешт [4].

Основні функції передбачають таке:

вивчення та аналіз проблемних питань у діяльності органів і підрозділів поліції стосовно дотримання прав і свобод людини;

подання керівництву поліції пропозицій щодо вдосконалення нормативно-правової бази відповідно до вимог міжнародних та національних договорів у галузі прав і свобод людини, а також рішень Європейського суду з прав людини;

організацію та проведення навчально-освітніх заходів з питань забезпечення прав і свобод людини, а також науково-методичного супроводження діяльності поліції щодо забезпечення прав і свобод людини; проведення перевірок дотримання прав і свобод людини в діяльності підрозділів ГУНП;

інспектування ізоляторів тимчасового тримання, надання керівництву поліції пропозицій щодо заходів реагування у разі виявлення порушень законодавства;

участь у незалежних службових розслідуваннях порушень прав і свобод людини;

розгляд звернень громадян, що належать до компетенції УзПЛ, з питань, пов'язаних з порушенням прав і свобод людини в діяльності органів і підрозділів поліції [4].

Як бачимо, все ж таки дублювання завдань та функцій відбувається, адже зазначені вище підрозділи Національної поліції фактично виконують їх. Так, наприклад, основним завданням інспекції з особового складу $\epsilon$ забезпечення повного, всебічного дослідження обставин надзвичайних подій за участю особового складу поліції, зокрема, застосування табельної вогнепальної зброї, загибелі та поранення поліцейських, дорожньо-транспортних пригод за їх участю, проведення службових розслідувань за актами злочинів, що вчинені поліцейськими.

Департамент внутрішньої безпеки Національної поліції України $€$ міжрегіональним територіальним органом у складі кримінальної поліції та згідно із законодавством України здійснює оперативно-розшукову діяльність. До основних завдань Департаменту належить формування та забезпечення реалізації заходів з питань внутрішньої безпеки в Національній поліції України, а також виявлення, попередження та припинення кримінальних правопорушень та корупційних діянь, що готуються або вчинені правниками органів та підрозділів Національної поліції України; захист посадових осіб Національної поліції України від перешкоджання їм у виконанні службових обов' язків [5].

Здійснення контролю за виконанням підрозділами головних управлінь Конституції України та інших законів України, указів Президента України та постанов Верховної Ради України, прийнятих відповідно до Конституції та законів України, актів Кабінету Міністрів України, нормативно-правових актів МВС України, інших актів законодавства України; а також здійснення в підрозділах головних управлінь систематичного аналізу та перевірок стану обліково-реєстраційної дисципліни $\epsilon$ основними завданнями управлінь організаційно-аналітичного забезпечення та оперативного реагування [6].

За рамками діяльності Національної поліції України функціонує уповноважений Верховної Ради України з прав людини, який здійснює парламентський контроль за додержанням прав і свобод людини та громадянина в Україні [7].

Аналіз чинного законодавства та практики його застосування дозволяє зробити наступні висновки. Працівники управління забезпечення прав людини Національної поліції України є так би мовити відомчими омбудсменами, які фактично $\epsilon$ контролюючими органами, що дублюють функції декількох підрозділів Національної поліції України та уповноваженого Верховної Ради України з прав людини. Доцільність функціонування даного інституту залишається під питанням в умовах реформування Національної поліції за принципами економічного використання сил та засобів.

Водночас слід зауважити, що напрямки роботи даних підрозділів обмежуються освітньою діяльністю, 


\section{Правове забезпечення адміністративної реформи}

налагодженням діалогу з громадськістю, аналітичною діяльності. Контроль, який входить до повноважень управлінь забезпечення прав людини Національної поліції, обмежується перевірками територіальних підрозділів, проте офіційна статистика з даного питання відсутня. Враховуючи викладене, також можна стверджувати про недостатню ефективність діяльності даного структурного підрозділу, який має виявляти факти порушення прав людини та вживати заходи до осіб, які вчинили дані дії.

На нашу думку, створення управлінь забезпечення прав людини Національної поліції $€$ позитивною спробою удосконалення інституційно-організаційних засобів забезпечення та захисту прав людини, проте потребує удосконалення застосовуваних прийомів та засобів їх діяльності. Акцент має робитися саме на викорененні в діяльності всіх органів та підрозділів Національної поліції порушень прав людини шляхом притягнення винних осіб до відповідальності. Звісно інші напрямки роботи даних управлінь мають місце бути, проте, як показує практика, методи переконання не завжди $\epsilon$ дієвими в нашій державі. Примусові заходи, застосовані до порушників-поліцейських, $є$ фактором попередження вчинення іншими подібних дій.

Наостанок наголосимо на необхідності взаємодії вказаних управлінь з Уповноваженим Верховної Ради України з прав людини, Департаментом внутрішньої безпеки Національної поліції України, інспекціями з особового складу Національної поліції України, які мають подібні повноваження, а отже їх взаємодія матиме оперативний та ефективний результат.

Висновки. Аналіз чинного законодавства України та практики його застосування дає змогу констатувати дублювання функцій Уповноваженого Верховної Ради України з прав людини, Департаменту внутрішньої безпеки Національної поліції України, інспекцій з особового складу Національної поліції України новоствореним структурним підрозділом Національної поліції України - управління забезпечення прав людини. Надалі вбачаємо необхідність вироблення чіткого розмежування повноважень названих державних органів із метою ефективного захисту прав та свобод людини в нашій державі.

\section{Література}

1. ЄСПЛ: 2017 року майже кожне десяте рішення про порушення стосувалося України. URL: http:// www.dw.com/uk/.

2. Князєв В.І. Конституційні гарантії прав, свобод та обов'язків людини і громадянина в Україні. Право України. 1998. № 11. С. 29-31.

3. Про Національну поліцію : Закон України від 2 липня 2015 р. № 580-VII. Голос України. 2015. № 141-142.

4. Управління забезпечення прав людини Національної поліції України. URL: https://www.npu.gov.ua/uk/ publish/article/1998717.

5. Департамент внутрішньої безпеки Національної поліції України. URL: https://www.npu.gov.ua/uk/publish/ article/1820018.

6. Про затвердження Типового положення про управління організаційно-аналітичного забезпечення та оперативного реагування головних управлінь Національної поліції України в Автономній Республіці Крим та м. Севастополі, областях, М. Києві : Наказ МВС України від 22 січня 2016 p. № 39. URL: http://zakon3.rada.gov.ua/laws/show/ z0216-16.

7. Про Уповноваженого Верховної Ради України з прав людини : Закон України від 23 грудня 1997 р. URL: http:// zakon5.rada.gov.ua/laws/show/776/97-\%D0\%B2\%D1\%80.

Кравченко І. С., кандидат юридичних наук, доцент, доцент кафедри адміністративного права, процесу та адміністративної діяльності Дніпропетровського державного університету внутрішніх справ 